Mr. E. L. J. Potts

Mr. Edward L. J. Potrs, who has been appointed to succeed Prof. Granville Poole, comes from a mining family, being one of four sons, three of whom graduated in mining at King's College, Newcastle. After taking first-class honours, he conducted research into ventilation problems and was awarded the M.Sc. $\mathrm{He}$ possesses the mine surveyor's and first-class manager's certificate of competency and was appointed lecturer in mining in 1940, and reader in 1946, at King's College. In addition to practical experience in Great Britain, he has studied mining methods abroad and is at present engaged with Prof. Fritzsche, of Aachen, in compiling a treatise on "Horizon Mining" sponsored by the National Coal Board. Mr. Potts has carried out a considerable amount of research and has many publications. His research includes the distribution of stress around underground excavations, using photo-elastic methods; the investigation of air-flow conditions in underground roadways and in mine fan installations; the development of an original design of a circular fluorescent-lighting unit for face and roadway lighting, and the application of anodized aluminium reflectors; and the design and operation of a fine. coal washing system incorporating a paraboloid cone equipped with jets. Mr. Potts was technical adviser to the Northumberland coal owners at Stage II of the Valuation of Northumberland Collieries under the Coal Mines Nationalization Act. $\mathrm{He}$ has been appointed mining adviser to the Peterlee Development Corporation, and is conducting subsidence surveys and advising on mining subsidence in relation to the development of a master plan for the new town.

\section{International Polarographic Congress in Prague}

A MeETing of some four hundred workers inter. ested in polarography was held in Prague during February 4-8. Visitors from Poland, Hungary, Roumania and Bulgaria were present. The congress was organized by the Centre of Researeh and Technical Development in Prague, under the presidency of Prof. J. Heyrovský, director of the Central Institute of Polarography, with Prof. R. Brdička, director of the Physico-chemical Institute of the Charles University, Prague, as vice-president. An evening meeting for visitors, held in the old palace of Sylva Taroucca, preceded the opening of the Congress, which was inaugurated in the large theatre of the Purkyne Medical Institute on February 5 by the Minister of Planning, Dr. J. Dolanský, and director of the Centre of Research and Technical Development, Prof. J. Fukátko. Dr. Dolanský spoke on the cardinal tasks of seience in building up socialism, and Prof. Fukátko on the role of planning in scientific research. Prof. J. Heyrovský then gave a review entitled "Fundamentals of Polarography". The proceedings of the Congress were divided into eight surveys, each of about an hour's duration, in which modern developments of polarography were summarized, and the discussion of papers submitted to the Congress. The following surveys were given : Vl. Majer, "Inorganic Analysis"; Vl. Hanuš, "Polarography of Organic Compounds" ; P. Zuman, "Organic Analysis"; F. Santavý, "Polarography in Biochemistry and Medicine"; J. Forejt, "Instruments for Oscillographic Polarography"; J. Heyrovský, "Applications of Oscillographic Polarography"; R. Brdička, "Kinetics of Electrode
Processes in Polarography". Fifty-five communications were presented. Reports on the communications and discussions will be published in full in three volumes, of which the first will also contain contributions from abroad not communicated at the Congress, in English, French and German, the second a full bibliography of polarographic papers from 1922 to 1950 , and the third actual reports of the meetings. Single volumes, which will appear about in April, will be sold to non-members of the Congress.

\section{National Central Library: Annual Report for 1949-50}

THE thirty-fourth annual report of the executive committee of the National Central Library, covering the year ending February 28, 1950 (pp. 30 ; London : National Central Library, 1950), refers to an increase in the Treasury grant-in-aid from $£ 19,000$ to $£ 22,500$, including a sum of $£ 1,000$ to offset the second stage in the discontinuance of the contribution from the Carnegie United Kingdom Irust. A satisfactory response was received to the attempt made in the financial year 1946-47 to increase the sum obtained from libraries of research, commercial and industrial organizations not participating in regional systems but making substantial calls on the Library's services. Total issues from or through the Library were 96,552 volumes, an increase of nearly three per cent on 1948-49; but the number of volumes issued to university libraries increased by 22.42 per cent to 12,786 , while 17,234 volumes were lent by the university libraries to other libraries. Volumes issued to the special outlier libraries, which now number 207 , increased from 6,732 in $1948-49$ to 7,404 , and 17,574 books were lent by these outlier libraries; books issued to libraries of government departments, research and industrial organizations increased from 9,405 to 11,903 volumes. Some 607 libraries are now co-operating in the regional systems, and they lent 164,152 volumes to other libraries in their own systems and 21,423 volumes to libraries in other regional systems and to non-regional libraries through the National Central Library. There was a striking development in international loans, 994 books being lent to twenty-three countries and 420 borrowed from nineteen countries. The activities of the British National Book Centre in arranging for the exchange of 'unwanted' books and periodicals between libraries of different types in Great Britain, between libraries in Britain and those in the Dominions and Colonies, and between British and foreign libraries, continued to expand.

\section{"Agronomia Angolana"}

THE third number of "Agronomia Angolana", published annually by the Serviços de Agricultura at Luanda, Portuguese West Africa (C.P. 1233), was issued in 1950, previous numbers being those for 1948 and 1949 (No. 1, pp. 204; No. 2, pp. 263; No. 3 , pp. $176 ; 20$ angolares each). Its aim, as stated by the editor, is the dissemination of informa. tion on agricultural investigations in progress at research stations in the Colony of Angola and elsewhere, and to promote exchange of ideas and of current knowledge. Certain articles of a general character are included, such as those describing the scope and programmes of work at individual agricultural experimental stations, and developments in the Colony's agriculture. Original papers are published on a variety of topics, including methods adopted in plant breeding, aspects of fruit growing, 